\title{
Chronic beta-adrenergic blockade prevents volume overload-induced re-localization and oxidation of soluble guanylyl cyclase
}

\author{
Yuchuan Liu', Louis Dell'Italia ${ }^{2}$, Victor Rizzo ${ }^{1,3}$, Emily J Tsai ${ }^{1, *^{*}}$ \\ From 6th International Conference on cGMP: Generators, Effectors and Therapeutic Implications \\ Erfurt, Germany. 28-30 June 2013
}

\begin{abstract}
Background
While $\beta$-adrenergic blockade is a cornerstone of heart failure therapy, its therapeutic role in chronic mitral regurgitation remains questionable. Animal studies and a small clinical trial have demonstrated cardiac functional improvement with $\beta_{1}$-adrenoceptor blocker metoprolol in chronic mitral regurgitation [1,2]. How $\beta_{1}$ AR-blockade halts functional decline of the volume-overloaded, eccentric hypertrophied heart is not well understood; anti-oxidant effects of $\beta$-blockade ( $\beta B$ ) may play a role. We recently demonstrated that volume-overload cardiac stress induces re-localization and microdomain-specific oxidation of the nitric oxide receptor soluble guanylyl cyclase (sGC) in the failing heart [3,4]. Given that nitric oxide-cyclic guanosine monophosphate (NO-cGMP) modulates cardiac contractility and protects against cardiac hypertrophy, we hypothesized that $\beta_{1}$ AR-blockade prevents oxidation of $\mathrm{sGC}$ and promotes myocardial NO-cGMP signaling in a microdomain-specific fashion.
\end{abstract}

\section{Materials and methods}

Volume-overload (VO) was established by chordal ruptureinduced mitral regurgitation (MR) in mongrel dogs. Some dogs were treated with metoprolol succinate $(100 \mathrm{mg}$ orally once daily; $M R+\beta B)$. Expression, localization, cyclase activity, and redox state of myocardial sGC were assessed in Control, MR, and MR+ $\beta B$ dogs.

\section{Results}

sGC $\alpha_{1}$ and $-\beta_{1}$ subunits were detected within and outside of caveolae-enriched lipid rafts $\left(\mathrm{Cav} 3^{+} \mathrm{LR}\right)$. In $M R$,

\footnotetext{
* Correspondence: emily.tsai@tuhs.temple.edu

${ }^{1}$ Cardiovascular Research Center, Temple University School of Medicine, Philadelphia, PA, 19140, USA

Full list of author information is available at the end of the article
}

total sGC $\alpha_{1}$ expression fell to nearly $50 \%$ of Control and re-localized away from $\mathrm{Cav}^{+} \mathrm{LR}$ to non-lipid raft microdomains (NLR). While overall $s G C \beta_{1}$ expression was also less in $M R+\beta B$, caveolae-localization of $s G C \beta_{1}$ was preserved. Overall NO-responsiveness of sGC remained intact in MR hearts, irrespective of $\beta B$ therapy. However, a potentiated response to heme/NO-independent sGC activator BAY 60-2770 suggested that a subset of sGC was heme-oxidized in MR but not in Control or $M R+\beta B$. Moreover, differential responses to BAY 60-2770 and NO were noted in Cav3 ${ }^{+}$LR and NLR microdomains. In Control hearts, responses to BAY 602770 and NO were similar within respective microdomains, suggesting a predominantly reduced form of sGC in both $\mathrm{Cav}^{+} \mathrm{LR}$ and NLR of Controls. In contrast, BAY 60-2770 response of NLR-localized sGC was potentiated in $M R$ but not in $M R+\beta B$ hearts, suggesting that $\beta B$ therapy prevented oxidation of NLR-localized sGC. Moreover, BAY 60-2770 responses of Cav $3^{+}$LR-localized sGC were not potentiated in any hearts, suggesting an anti-oxidation protection associated with caveolae-localization. These changes in caveolae-localization and redox state of sGC were also reflected by microdomain distribution of VASP phosphorylation.

\section{Conclusion}

$\beta_{1} \mathrm{AR}$ blocker mediated cardioprotection in the volumeoverloaded heart is associated with enhanced microdomain specific myocardial NO-cGMP signaling, both within and outside of caveolae. Such prevention of volume overload-induced spatial and redox dysregulation of myocardial sGC suggests novel strategies to enhancing cardioprotective NO-cGMP signaling.

(c) 2013 Liu et al; licensee BioMed Central Ltd. This is an Open Access article distributed under the terms of the Creative Commons 


\section{Authors' details}

${ }^{1}$ Cardiovascular Research Center, Temple University School of Medicine, Philadelphia, PA, 19140, USA. ²Division of Cardiovascular Disease, Department of Medicine, University of Alabama Birmingham School of Medicine, Birmingham, AL, 35233, USA. ${ }^{3}$ Department of Anatomy and Cell Biology, Temple University School of Medicine, Philadelphia, PA, 19140, USA. ${ }^{4}$ Section of Cardiology, Department of Medicine, Temple University School of Medicine, Philadelphia, PA, 19140, USA.

Published: 29 August 2013

\section{References}

1. Pat B, Killingsworth C, Denney T, Zheng J, Powell P, Tillson M, Dillon AR, Dell'talia LJ: Dissociation between cardiomyocyte function and remodeling in beta-adrenergic receptor blockade in isolated canine mitral regurgitation. Am J Physiol Heart Circ Physiol 2008, 295:H2321-H2327.

2. Ahmed Ml, Aban I, Lloyd SG, Gupta H, Howard G, Inusah S, Peri K, Robinson J, Smith P, McGiffin DC, Schiros CG, Denney T Jr, Dell'Italia L: A randomized controlled phase $\mathrm{llb}$ trial of beta(1)-receptor blockade for chronic degenerative mitral regurgitation. J Am Coll Cardiol 2012, 60:833-838.

3. Tsai EJ, Liu Y, Koitabashi N, Bedja D, Danner T, Jasmin JF, Lisanti MP, Friebe A, Takimoto E, Kass DA: Pressure-overload induced subcellular relocalization/oxidation of soluble guanylyl cyclase in the heart modulates enzyme stimulation. Circ Res 2012, 110:295-303.

4. Liu Y, Dillon AR, Tillson M, Makarewich C, Nguen V, Dell'Italia L, Sabria A, Rizzo V, Tsai EJ: Volume overload induces differential spatiotemporal regulation of myocardial soluble guanylyl cyclase in eccentric hypertrophy and heart failure. J Mol Cell Cardiol 2013, 60:72-83.

doi:10.1186/2050-6511-14-S1-O22

Cite this article as: Liu et al: Chronic beta-adrenergic blockade prevents volume overload-induced re-localization and oxidation of soluble guanylyl cyclase. BMC Pharmacology and Toxicology 2013 14(Suppl 1):022.

\section{Submit your next manuscript to BioMed Central and take full advantage of:}

- Convenient online submission

- Thorough peer review

- No space constraints or color figure charges

- Immediate publication on acceptance

- Inclusion in PubMed, CAS, Scopus and Google Scholar

- Research which is freely available for redistribution

Submit your manuscript at www.biomedcentral.com/submit 